\title{
Front Matter: Volume 10848
}

"Front Matter: Volume 10848," Proc. SPIE 10848, Micro-Optics and MOEMS, 1084801 (12 December 2018); doi: 10.1117/12.2521731

SDIE Event: International Symposium on Optoelectronic Technology and SPIE. Application 2018, 2018, Beijing, China 


\title{
PROCEEDINGS OF SPIE
}

\section{Micro-Optics and MOEMS}

\author{
Yuelin Wang \\ Huikai Xie \\ Editors
}

\section{2-24 May 2018 \\ Beijing, China}

Organized by

Chinese Society for Optical Engineering (CSOE) (China)

Photoelectronic Technology Committee, Chinese Society of Astronautics (China)

Photoelectronic Industrialization Committee, CHIA (China)

Department of Cooperation and Coordination for Industry, Academe and Research, CHIA (China)

Science and Technology on Low-light-level Night Vision Laboratory (China)

Sponsored by

Division of Information and Electronic Engineering of Chinese Academy of Engineering (China) Chinese Society for Optical Engineering (CSOE) (China)

Published by

SPIE

\section{Volume 10848}


The papers in this volume were part of the technical conference cited on the cover and title page. Papers were selected and subject to review by the editors and conference program committee. Some conference presentations may not be available for publication. Additional papers and presentation recordings may be available online in the SPIE Digital Library at SPIEDigitalLibrary.org.

The papers reflect the work and thoughts of the authors and are published herein as submitted. The publisher is not responsible for the validity of the information or for any outcomes resulting from reliance thereon.

Please use the following format to cite material from these proceedings:

Author(s), "Title of Paper," in Micro-Optics and MOEMS, edited by Yuelin Wang, Huikai Xie, Proceedings of SPIE Vol. 10848 (SPIE, Bellingham, WA, 2018) Seven-digit Article CID Number.

ISSN: 0277-786X

ISSN: 1996-756X (electronic)

ISBN: 9781510623385

ISBN: 9781510623392 (electronic)

Published by

SPIE

P.O. Box 10, Bellingham, Washington 98227-0010 USA

Telephone +1 3606763290 (Pacific Time) · Fax +1 3606471445

SPIE.org

Copyright (C) 2018, Society of Photo-Optical Instrumentation Engineers.

Copying of material in this book for internal or personal use, or for the internal or personal use of specific clients, beyond the fair use provisions granted by the U.S. Copyright Law is authorized by SPIE subject to payment of copying fees. The Transactional Reporting Service base fee for this volume is $\$ 18.00$ per article (or portion thereof), which should be paid directly to the Copyright Clearance Center (CCC), 222 Rosewood Drive, Danvers, MA 01923. Payment may also be made electronically through CCC Online at copyright.com. Other copying for republication, resale, advertising or promotion, or any form of systematic or multiple reproduction of any material in this book is prohibited except with permission in writing from the publisher. The CCC fee code is 0277 $786 \mathrm{X} / 18 / \$ 18.00$.

Printed in the United States of America.

Publication of record for individual papers is online in the SPIE Digital Library.

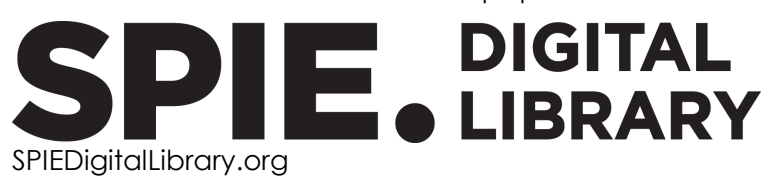

SPIEDigitalLibrary.org

Paper Numbering: Proceedings of SPIE follow an e-First publication model. A unique citation identifier (CID) number is assigned to each article at the time of publication. Utilization of CIDs allows articles to be fully citable as soon as they are published online, and connects the same identifier to all online and print versions of the publication. SPIE uses a seven-digit CID article numbering system structured as follows:

- The first five digits correspond to the SPIE volume number.

- The last two digits indicate publication order within the volume using a Base 36 numbering system employing both numerals and letters. These two-number sets start with 00, 01, 02, 03, 04, 05, 06, 07, 08, 09, OA, OB ... 0Z, followed by 10-1Z, 20-2Z, etc. The CID Number appears on each page of the manuscript. 


\title{
Contents
}

\author{
$\checkmark \quad$ Authors \\ vii Conference Committee \\ ix Introduction
}

MICRO-OPTICS AND MOEMS

1084802 Intensifier performance test technology development [10848-1]

1084803 Orbital rotation of multi-particle arrays in a dual-fiber optical trap [10848-2]

$1084804 \quad$ Refractive index detection of nanolitre samples in a microfluidic chip with a Michelson interferometer [10848-3]

1084805 Monte Carlo investigation of cell defects on detection properties in radial packed square-pore micro-channel optics [10848-4]

1084806 Spoof surface plasmons on the corrugated metal surface with gradient groove depths [10848-5]

1084807 Study on angle detection capability of silicon waveguide grating coupler [10848-6]

1084808 Low loss terahertz devices based on polymer substrate [10848-7]

1084809 Micro-scanning mechanism design based on dynamic model [10848-8]

10848 OA Research on the graphene oxide's dielectric constant at the microwave frequency of $9.231 \mathrm{GHz}$ [10848-9]

10848 OB Ultra-sensitive fluorescence detection based on helical micro optical fiber [10848-10]

10848 OC Split nanofocusing spots beyond diffraction limit via a new near-field plasmonic structure [10848-11]

10848 OD Design and analysis of a novel connective locking mechanism for future space mirrors assembly [10848-12]

$10848 \mathrm{OE} \quad$ Resonance characteristics of TE mode in slotted photonic crystal microring resonator [10848-15]

$10848 \mathrm{OF} \quad$ Estimating relative extent of scattering loss due to sidewall roughness in slot waveguides by $\mathrm{n}_{\mathrm{w}}$ model [10848-16] 
Optical design and analysis of a high resolution MOEMS accelerometer based on diffraction grating [10848-17]

$10848 \mathrm{OH} \quad$ Progress in atomic layer deposition based microchannel plate [10848-18] 


\section{Authors}

Numbers in the index correspond to the last two digits of the seven-digit citation identifier (CID) article numbering system used in Proceedings of SPIE. The first five digits reflect the volume number. Base 36 numbering is employed for the last two digits and indicates the order of articles within the volume. Numbers start with 00, 01, 02, 03, 04, 05, 06, 07, 08, 09, OA, OB...0Z, followed by 10-12, 20-2Z, etc.

Bai, Jian, OG

Bo, Tiezhu, 05

Cai, Hua, 05

Chen, Huiqing, 04

Chen, Peiwen, OG

Chen, Qinnan, OB

Chen, Xiuyan, OA

Chen, Yanjun, OC

Chu, Yunting, OA

Dang, Suihu, 08

Fan, Shi-xun, 09

Fan, Xuewu, OD

Fang, $\mathrm{Ke}, \mathrm{OB}$

Fang, Weidong, OG

Gao, Yang, 07

Geng, Anbing, OG

Guo, Zhe, OC

$\mathrm{Hu}$, WenGang, 02

Huang, Kangsheng, 05

Huang, Li-wei, 09

Jia, Jinsheng, 05

Jiao, Tianyi, OA

Kong, Mei, OE, OF

Li, Hengnian, 03

$\mathrm{Li}$, Liangsheng, 06

Li, Qing, 05, OH

Li, Songbai, 08

Li, Xiu, OA

Li, Xupeng, OD

Li, Yanqiu, OC

Li, Yuanyuan, 03

Lian, Jiao, $\mathrm{OH}$

Liao, Jiali, 07

Liu, Bin, 02

Liu, Chang, 05

Liu, Hui, 05, $\mathrm{OH}$

Liu, Juan, 05

Liu, Junshan, 04

Liu, Kun, 04

Liu, Kunshan, 03

Liv, Xin, OE

Liu, Yanfei, 07

Liv, Yong-Qiang, 06

LU, Qianbo, OG

Luo, Yangcheng, 04

Mao, Hongyan, 08

Mei, Xuecui, OB

Pan, Debin, OG

Qu, Yanjun, OD
Shi, Jinfeng, OD

Shi, Xiaoxuan, 05

Song, Jiang-peng, 09

Sun, Daoheng, OB

Sun, Guang-li, 09

Sun, Qiyun, 07

Sun, Yong, 05

Wang, Caili, 05

Wang, Haitao, OG

Wang, Jiuwang, 05

Wang, Wei, OD

Wang, Xinqi, 03

Wang, Xueping, OE

Wang, Yu, OF

Wu, Chuang, OA

Wu, XiShan, 02

Xia, Liangping, 08

Xiao, Guangzong, 03

Xie, Shiyong, 05

$\mathrm{Xu}$, Jun, 07

$\mathrm{Xu}, \mathrm{TaO}, \mathrm{OH}$

$\mathrm{XU}$, Yameng, $\mathrm{OE}$

$\mathrm{Xu}$, Yanglei, $\mathrm{OH}$

Yan, Wenjuan, 08

Yao, Yuan, OG

Yin, Hongcheng, 06

Yu, Changmin, $O A$

Yu, Guiying, OA

Zhang, Lijun, 03

Zhang, Xinqun, 08

Zhao, Keqin, OA

Zhou, Zhanrong, 07

Zhu, Changyong, 04 
Proc. of SPIE Vol. 10848 1084801-6

Downloaded From: https://www.spiedigitallibrary.org/conference-proceedings-of-spie on 26 Apr 2023 Terms of Use: https://www.spiedigitallibrary.org/terms-of-use 


\title{
Conference Committee
}

\author{
Conference Chair
}

Guangjun Zhang, Southeast University (China)

\section{Conference Co-chairs}

Junhao Chu, Shanghai Institute of Technical Physics (China)

Qionghai Dai, Tsinghua University (China)

Dianyuan Fan, Shenzhen University (China)

Jiancheng Fang, Beihang University (China)

Gu Min, Royal Melbourne Institute of Technology University (Australia)

Desheng Jiang, Wuhan University of Technology (China)

Huilin Jiang, Changchun University of Science and Technology (China)

Lin Li, The University of Manchester (United Kingdom)

Yueguang Lv, Chinese Academy of Engineering (China)

Zhejin Liu, National University of Defense Technology (China)

Wang Xiaomo, China Academy of Electronics and Information Technology (China)

Huaming Wang, Beihang University (China)

Lijun Wang, Changchun Institute of Optics, Fine Mechanics and Physics (China)

Wei Wang, China Aerospace Science and Technology Corporation (China)

Jianyu Wang, Shanghai Branch of Chinese Academy of Sciences (China)

Zuyan Xu, The Technical Institute of Physics and Chemistry (China)

Jiubin Tan, Harbin Institute of Technology (China)

Jianquan Yao, Tianjin University (China)

Hao Yin, China Electronic Systems Engineering Corporation (China)

Shaohua Yu, Wuhan Research Institute of Posts and Telecommunications (China)

Renhe Zhang, Institute of Acoustics (China)

Zisen Zhao, Wuhan Research Institute of Posts and Telecommunications (China)

Liwei Zhou, Beijing Institute of Technology (China)

Shouhuan Zhou, North China Research Institute of Electro-optics (China)

Zhongliang Zhu, Southwest Electronic Telecom Technology Research Institute (China) 
Program Committee

Byoungho Lee, Seoul National University (Korea, Republic of)

Liangcai Cao, Tsinghua University (China)

Weibiao Chen, Shanghai Institute of Optics and Fine Mechanics

(China)

Haimei Gong, Shanghai Institute of Technical Physics (China)

Sen Han, University of Shanghai for Science and Technology (China)

Huikai Xie, University of Florida (United States)

John McBride, University of Southampton (United Kingdom)

Yanbiao Liao, Tsinghua University (China)

Dong Liu, Zhejiang University (China)

Jian Liu, Harbin Institute of Technology (China)

Jin Lu, Tianjin Jinhang Institute of Technical Physics (China)

Mircea Guina, Tampere University of Technology (Finland)

Shibin Jiang, AdValue Photonics, Inc. (United States)

Guohai Situ, Shanghai Institute of Optics and Fine Mechanics (China)

Hongbo Sun, Tsinghua University (China)

Yongtian Wang, Beijing Institute of Technology (China)

Yuelin Wang, Shanghai Institute of Microsystem and Information

Technology (China)

Renhe Zhang, Institute of Acoustics (China)

Xuejun Zhang, Changchun Institute of Optics, Fine Mechanics and

Physics (China)

Pu Zhou, National University of Defense Technology (China)

Zhongliang Zhu, Southwest Electronic Telecom Technology Research Institute (China)

\section{Session Chairs}

1 Micro Optics and MOEMS I

Huikai Xie, University of Florida (United States)

2 Micro Optics and MOEMS II

Frederic Zamkotsian, Centre National de la Recherche Scientifique (France)

3 Micro Optics and MOEMS III

Wei-Chuan Shih, University of Houston (United States)

$4 \quad$ Micro Optics and MOEMS IV

Wengang Wu, Peking University (China) 


\section{Introduction}

The International Symposium on Optoelectronic Technology and Application 2018 (OTA 2018) is the annual conference of the Chinese Society for Optical Engineering. It continues to be one of the largest academic and industrial conferences in the field of optical and optoelectronic technology in China. This year's program included academic exchanges, industry exhibitions, and cooperation negotiations together in one event. There were five technical conferences, seven exhibition themes, and 600 technical negotiations. We sincerely hope that this event continues to promote research and development of optoelectronic technology and to enhance international cooperation in the optical and optoelectronic fields.

OTA 2018 was sponsored by The Division of Information and Electronic Engineering of the Chinese Academy of Engineering (China), and The Chinese Society for Optical Engineering (CSOE) (China). The conference was organized by the Chinese Society for Optical Engineering (CSOE) (China), the Photoelectronic Technology Committee, the Chinese Society of Astronautics (China), the Photoelectronic Industrialization Committee, CHIA (China), the Department of Cooperation and Coordination for Industry, Academe, and Research, CHIA (China), and the Science and Technology on Low-light-level Night Vision Laboratory (China). We received more than 759 contributions from more than 15 countries, including the United States, United Kingdom, Germany, France, Spain, Australia, Canada, Mexico, Brazil, Japan, Republic of Korea, Thailand, Singapore, Russian Federation and China. There were more than 400 contributions published in SPIE Proceedings, including 70 contributions from invited speakers. After careful discussion, six keynote speeches were selected and presented by famous scientists from the United States, United Kingdom, Republic of Korea, and China. There were 138 excellent invited talks, 45 from overseas, that reflected first-class level in the field of optics and photonics technology. On behalf of the OTA 2018 Organizing Committee, I would like to express thanks to all the invited speakers and authors for their contributions and support.

Finally, on behalf of the other Co-chairmen and the Organizing Committee, I would like to heartily thank our sponsors and cooperating organizers for all they have done for the conference, and to all of the participants and friends for their interests and efforts in helping us to make the conference a success. Thanks also to the Program Committee for their effective work and valuable advice, especially the Secretariat, and to the staff of SPIE for their tireless efforts and outstanding service preparing and publishing the proceedings.

We hope to see you next year!

\section{Guangjun Zhang}


Proc. of SPIE Vol. 10848 1084801-10 Downloaded From: https://www.spiedigitallibrary.org/conference-proceedings-of-spie on 26 Apr 2023
Terms of Use: https://www.spiedigitallibrary.org/terms-of-use 